\title{
Fever and asplenia: a dangerous association
}

\author{
Halil Yildiz, ${ }^{1}$ Jean Cyr Yombi ${ }^{2}$
}

Medecine Interne, Cliniques Universitaires Saint-Luc, Brussels, Belgium ${ }^{2}$ Internal Medicine and Perioperative Medicine, UniversitÃ@ catholique de Louvain, Brussels, Belgium

\section{Correspondence to} Dr Halil Yildiz, halil.yildiz@ uclouvain.be, h_tur.bel@ hotmail.com

Accepted 24 May 2017

\section{CrossMark}

To cite: Yildiz H, Yombi JC. BMJ Case Rep Published Online First: [please include Day Month Year]. doi:10.1136/bcr-2017220513

\section{DESCRIPTION}

A 77-year-old splenectomised woman presented with temperatures reaching $38.5^{\circ} \mathrm{C}$ in the last 24 hours. The clinical presentation was non-specific and blood tests came back normal: a diagnosis of acute gastroenteritis was made. The patient's clinical state then deteriorated rapidly; she developed septic shock, acute renal failure, disseminated intravascular coagulation and purpura fulminans with peripheral necrosis of toes and fingers (figure $1 \mathrm{~A}, \mathrm{~B}$ ), as complications of a pneumococcaemia. Following appropriate antibiotic therapy and supportive care, the patient recovered but had to undergo transmetatarsal and finger amputations(figure $1 \mathrm{C}, \mathrm{D}$ ).

Fever in patients with asplenia can be the initial, and sometimes sole, sign of a severe infection. It should never be trivialised. Moreover, other clinical signs and symptoms in patients with asplenia with severe infections, can be very non-specific (fever, chills, sore throat, diarrhoea, vomiting and muscle aches). Clinical evolution can be abrupt even with antimicrobial therapy and deterioration can be seen

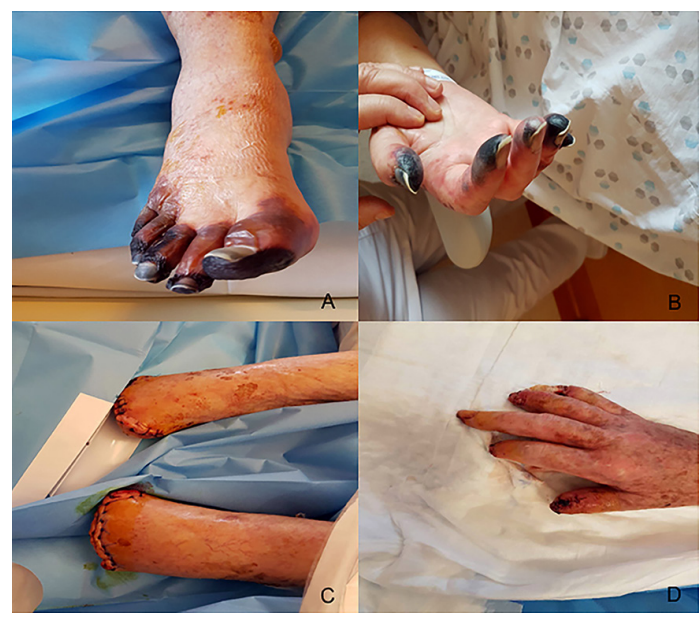

Figure 1 Necrosis of the (A) toes and (B) fingers in the context of disseminated intravascular coagulation. Clinical evolution following (C) transmetatarsal and (D) finger amputations. over minutes or hours. It is not rare for such patients to develop disseminated intravascular coagulation.

Streptococcus pneumoniae is the most common pathogen causing disease in patients with asplenia. Other bacteria such as Haemophilus influenzae type b, Neisseria meningitidis, Escherichia coli and Staphylococcus aureus can also be found. ${ }^{1}$ Antibiotic therapy must be given promptly pending results of blood cultures, in an attempt to decrease the mortality and morbidity of episodes of sepsis in this setting. Ceftriaxone, either intravenous or intramuscular, is an excellent first choice of antibiotic. Indeed, ceftriaxone is active against $S$. pneumoniae, $H$. influenzae, N. meningitidis and many community-acquired Gram-negative bacilli, including capnocytophaga. $^{2}$ Patients with asplenia should receive all indicated vaccinations including pneumococcal conjugate and polysaccharide vaccines.

\section{Learning points}

- Patients with asplenia are at high risk of severe septicaemia that are fatal in up to $50 \%$ of cases.

- Antimicrobials should always be administered pending results of blood cultures in splenectomised patients presenting with fever.

Contributors Both authors equally contributed in writing of this paper

Competing interests None declared.

Patient consent Obtained.

Provenance and peer review Not commissioned; externally peer reviewed.

(c) BMJ Publishing Group Ltd (unless otherwise stated in the text of the article) 2017. All rights reserved. No commercial use is permitted unless otherwise expressly granted.

\section{REFERENCES}

1 Ellison AM, Ota KV, McGowan KL, et al. Epidemiology of bloodstream infections in children with sickle cell disease. Pediatr Infect Dis J 2013:32:560-3.

2 Rubin LG, Schaffner W. Care of the asplenic patient. N Engl J Med Overseas Ed 2014;371:349-56.

Copyright 2017 BMJ Publishing Group. All rights reserved. For permission to reuse any of this content visit http://group.bmj.com/group/rights-licensing/permissions.

BMJ Case Report Fellows may re-use this article for personal use and teaching without any further permission.

Become a Fellow of BMJ Case Reports today and you can:

- Submit as many cases as you like

- Enjoy fast sympathetic peer review and rapid publication of accepted articles

- Access all the published articles

- Re-use any of the published material for personal use and teaching without further permission

For information on Institutional Fellowships contact consortiasales@bmjgroup.com

Visit casereports.bmi.com for more articles like this and to become a Fellow 